\title{
The Application of Ribosome Engineering to Natural Product Discovery and Yield Improvement in Streptomyces
}

\author{
Saibin Zhu ${ }^{1}$, Yanwen Duan ${ }^{1,2,3, *}$ and Yong Huang ${ }^{1,3, *(\mathbb{D})}$ \\ 1 Xiangya International Academy of Translational Medicine at Central South University, \\ Changsha 410013, Hunan, China \\ 2 Hunan Engineering Research Center of Combinatorial Biosynthesis and Natural Product Drug Discovery, \\ Changsha 410011, Hunan, China \\ 3 National Engineering Research Center of Combinatorial Biosynthesis for Drug Discovery, \\ Changsha 410011, Hunan, China \\ * Correspondence: ywduan66@csu.edu.cn (Y.D.); jonghuang@csu.edu.cn (Y.H.)
}

Received: 29 July 2019; Accepted: 27 August 2019; Published: 30 August 2019

\begin{abstract}
Microbial natural product drug discovery and development has entered a new era, driven by microbial genomics and synthetic biology. Genome sequencing has revealed the vast potential to produce valuable secondary metabolites in bacteria and fungi. However, many of the biosynthetic gene clusters are silent under standard fermentation conditions. By rational screening for mutations in bacterial ribosomal proteins or RNA polymerases, ribosome engineering is a versatile approach to obtain mutants with improved titers for microbial product formation or new natural products through activating silent biosynthetic gene clusters. In this review, we discuss the mechanism of ribosome engineering and its application to natural product discovery and yield improvement in Streptomyces. Our analysis suggests that ribosome engineering is a rapid and cost-effective approach and could be adapted to speed up the discovery and development of natural product drug leads in the post-genomic era.
\end{abstract}

Keywords: ribosome engineering; strain improvement; natural products; Streptomyces

\section{Introduction}

Streptomycetes are proficient producers of bioactive natural products, such as antibiotics (streptomycin and daptomycin), anticancer agents (bleomycin and doxorubicin), immunosuppressants (rapamycin), and agents used in veterinary medicine and agriculture (avermectins and spinosyn) [1-3]. Many Streptomyces natural products or their derivatives are also essential tools to discover new biology [4]. Rapamycin, a macrocyclic polyketide discovered from Streptomyces hygroscopicus in 1972, simultaneously binds FKBP12 and the mammalian target of rapamycin (mTOR) [5]. These studies led to the discovery of mTOR complex 1 and mTOR complex 2, which regulate protein synthesis or cellular metabolism in mammalian cells [6]. Several rapalogs, derivatives of the parent rapamycin, are useful in the treatment of renal cell carcinoma [7]. Rapamycin-inspired macrocycles recently became drug leads for the treatment of kidney ischaemia reperfusion injury [8].

The genome sequences of Streptomyces avermitilis and Streptomyces coelicolor A3(2) reveal that they contain 25 or 22 biosynthetic gene clusters (BGCs), respectively $[9,10]$. These surprising findings at the beginning of the 21st century suggest that most BGCs are silent under standard culture conditions and that there is a huge biosynthetic potential in the genus of Streptomyces. Since there are over 11,500 actinobacterial genomes listed in the Joint Genome Institute genome databases and the Genbank, the current discovered natural products from Streptomyces or Actinomyces are only the tip of an 
iceberg [11-13]. In addition, there is a huge need to increase the yield of many approved natural products-based drugs, and many of them are on the list of essential medicines recommended by the World Health Organization, such as the antibiotics vancomycin, streptomycin, and ivermectin, the semisynthetic derivative of avermectins, as well as antitumor agents bleomycin, dactinomycin, and daunorubicin [14] (Figures 1 and 2). The shortage of these medicines could precipitate a major public health crisis in any modern society.

Ribosome engineering is an approach to discover microbes with certain spontaneous mutations in their ribosome or RNA polymerase, through screening antibiotic-resistant mutants on Petri dishes. Some selected mutants may have elevated secondary metabolite production or produce new series of natural products with interesting biological activities. Ochi and co-workers discovered a streptomycin-resistant TK24 strain in the study of the model Streptomyces strain Streptomyces lividans in 1996 [15]. This natural mutant has a K88N mutation in the rpsL gene, which encodes ribosomal protein $\mathrm{S} 12$ and produces the well-studied blue pigment antibiotic actinorhodin (Act) (23). They and others were subsequently able to use a streptomycin screen to discover other mutations in $r p s L$ in different Streptomyces strains. Rifampicin was later used to screen for mutants with elevated secondary metabolite production and spontaneous mutation in the rpoB gene encoding the RNA polymerase $\beta$ subunit. Apart from mutations conferring resistance to streptomycin or rifampicin, other antibiotics, such as gentamicin, paromomycin, geneticin, fusidic acid, thiostrepton, and lincomycin, have also been successfully applied to screen for mutants with elevated levels of secondary metabolite production.

In the past two decades, this approach has been widely used for increasing the production of bioactive molecules in many bacterial species and for activating silent or poorly expressed BGCs in the post-genomic era. Recently, there have been several excellent reviews to discuss various aspects of ribosome engineering and synthetic biology approaches to engineer cellular metabolism [16-18]. In this short review, we focus on the discussion of the applications and mechanism of ribosome engineering to natural product discovery and yield improvement in Streptomyces. Our analysis suggests that ribosome engineering is a rapid and cost-effective approach and could be adapted to speed up the discovery and development of natural product drug leads in the post-genomic era.

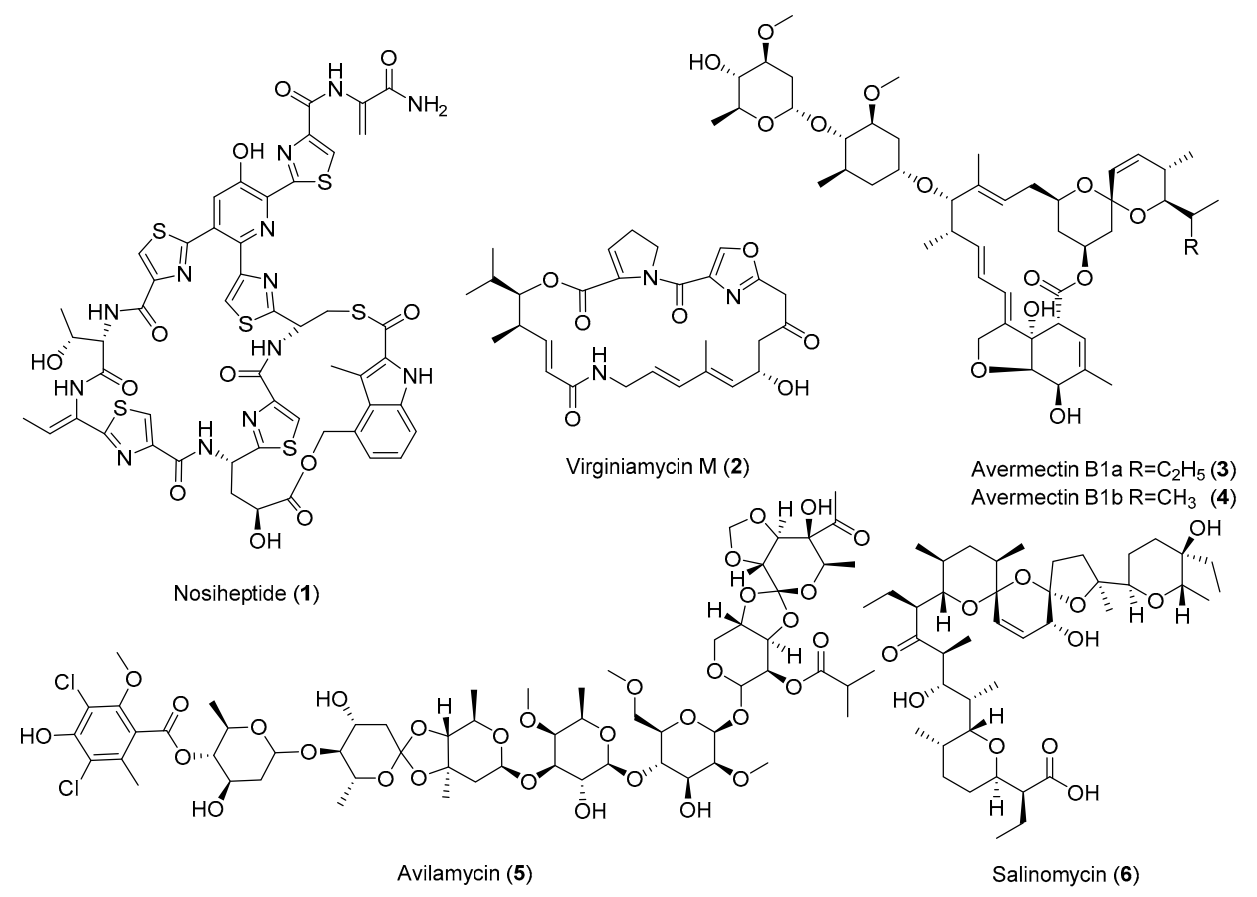

Figure 1. Representative structures of overproduced compounds useful in agriculture and veterinary medicine through ribosome engineering. 


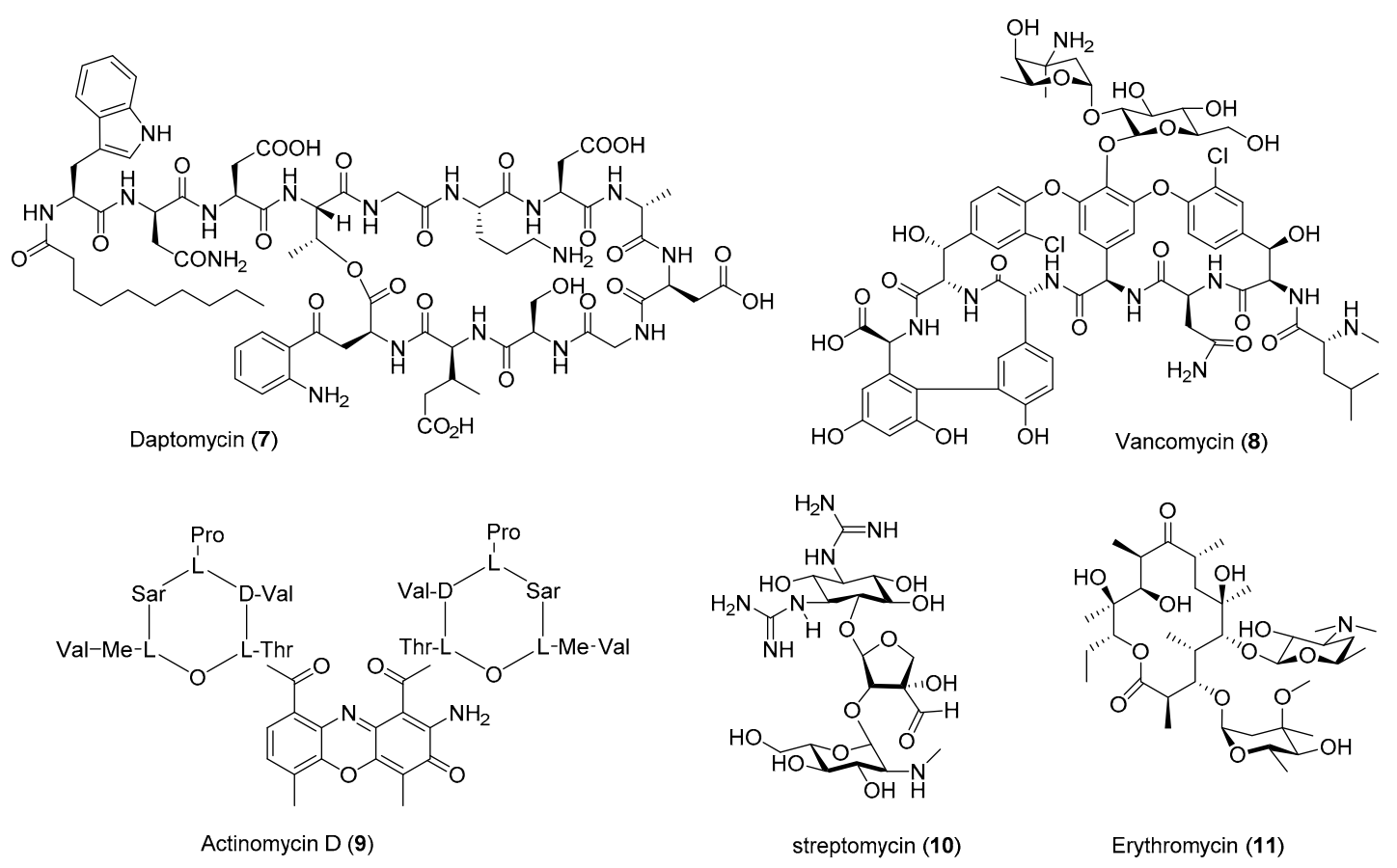

Figure 2. Representative structures of overproduced clinical medicines through ribosome engineering.

\section{Application of Ribosome Engineering to Increase Antibiotic Production}

Many Streptomyces strains isolated from nature have low yields of the produced natural products under laboratory fermentation conditions. Thus, these strains typically need significant optimization for pilot- or industrial-scale production. Traditional strain improvements may involve mutagenesis using chemical mutagens or physical methods such as UV or $\gamma$-irradiation [19]. Many of the current strain improvement methods include genome shuffling [20,21], heterologous expression [22], and metabolic pathway engineering [23]. The emerging tools in synthetic biology would completely refactor the whole BGC of certain natural products, using the designed genetic parts and circuits $[17,18]$. This could be done even on a genomic scale using de novo synthetic DNAs [24]. All these emerging technologies would contribute to our understanding of the whole metabolic cellular network of given cells, which would enable the creation of a cell factory for the precise control of gene expression and the biosynthesis of a given product. However, most of these methods would require the understanding and establishment of a genetic system in the targeted organism and sophisticated molecular biology techniques. The application of ribosome engineering is rather straightforward, involving the screening and isolation of the mutants resistant to certain antibiotics (Tables 1 and 2 and Figures 1-4).

Table 1. Summary of Streptomyces strains used for ribosome engineering.

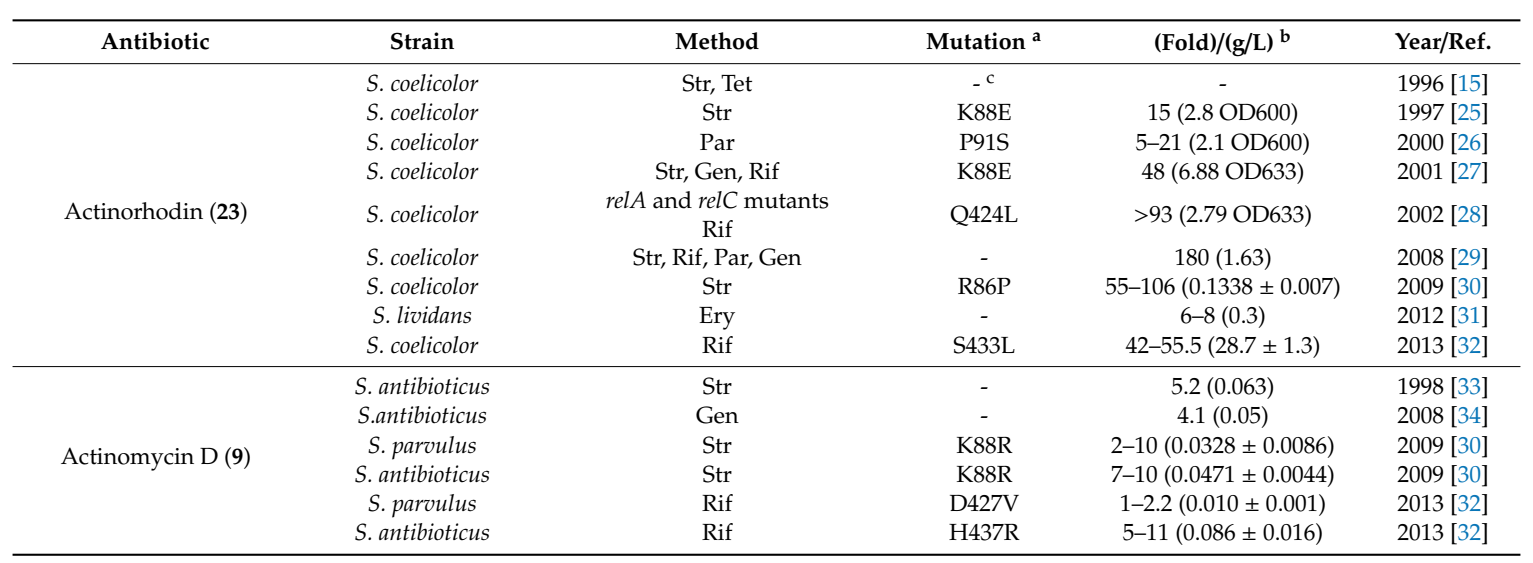


Table 1. Cont.

\begin{tabular}{|c|c|c|c|c|c|}
\hline Antibiotic & Strain & Method & Mutation $^{a}$ & (Fold)/(g/L) ${ }^{b}$ & Year/Ref. \\
\hline Avermectins $(3,4)$ & S. avermitilis & frr overexpression & - & $3-3.7(>0.8)$ & 2010 [35] \\
\hline Avilamycin (5) & S. viridochromogenes & ${ }^{60} \mathrm{Co} \gamma$-ray, GS, Str & $\mathrm{K} 43 \mathrm{~N}$ & $36.8(1.4)$ & $2013[36]$ \\
\hline Chloramphenicol (21) & S. coelicolor & Str, Rif, HE & - & $20-40(-)$ & 2011 [37] \\
\hline \multirow{2}{*}{ Daptomycin (7) } & S. roseosporus & Ple & - & $1.3(>0.08)$ & 2013 [38] \\
\hline & S. roseosporus & Neo, Gen, Rif, Par, GS ${ }^{a}$ & - & $4(0.324)$ & 2018 [39] \\
\hline Formycin A (28) & S. lavendulae & Str & $\mathrm{R} 440 \mathrm{H}$ & $2.4-4.6(0.055 \pm 0.014)$ & 2013 [32] \\
\hline \multirow{2}{*}{ Fredericamycin A (15) } & S. chattanoogensis & Str & - & $26(0.26)$ & 1998 [33] \\
\hline & S. somaliensis & Rif & $\mathrm{R} 444 \mathrm{H}$ & $3(0.6795 \pm 0.0158)$ & 2015 [41] \\
\hline Milbemycin $(19,20)$ & S. bingchenggensis & $\mathrm{CM}$, Str, $\mathrm{UV}$ & - & $1.8(1.45)$ & 2009 [42] \\
\hline Nosiheptide (1) & S. actuosus & ${ }^{60} \mathrm{Co} \gamma$-irradiation, $\mathrm{LiCl}$, Str, GS & K88R & $9.2(1.54)$ & $2014[43]$ \\
\hline \multirow[b]{2}{*}{ Streptomycin (10) } & S. griseus & Gen & - & $10(0.3)$ & 2008 [34] \\
\hline & S. griseus & Rif & Q424K & $2.4-6.0(0.178 \pm 0.027)$ & 2013 [32] \\
\hline \multirow{2}{*}{ Tiancimycin A (17) } & S. sp. CB03234 & Rif & L422P & $40(0.0225 \pm 0.0031)$ & 2016 [47] \\
\hline & S. sp. CB03234 & Str & $\mathrm{K} 43 \mathrm{~N}$ & $45(0.0137 \pm 0.0003)$ & 2019 [49] \\
\hline Tiancimycins D (14) & S. sp. CB03234 & Str & $\mathrm{K} 43 \mathrm{~N}$ & $109(0.0192 \pm 0.0004)$ & 2019 [49] \\
\hline \multirow{2}{*}{ Toyocamycin (16) } & S. diastatochromogenes & frr overexpression & - & $1.46(>0.6)$ & 2014 [50] \\
\hline & S. diastatochromogenes & Rif & $\mathrm{H} 437 \mathrm{Y}$ & $4.5(0.68)$ & $2016[51]$ \\
\hline \multirow{2}{*}{$\begin{array}{c}\text { Virginiamycin (2) } \\
\text { 6'-Deoxy-bleomycin Z } \\
(\mathbf{1 2})\end{array}$} & S. virginiae & UV, GS, Str & - & $11.6(0.251)$ & 2018 [52] \\
\hline & S. flavoviridis & UV, Str, Gen, Rif & - & $7(0.07)$ & 2018 [53] \\
\hline
\end{tabular}

The abbreviations are as follows: GS, genome shuffling; HE, heterologous gene expression; CM, chemical mutation; HEE, high energy electron; HT, high throughput. The abbreviations Ple, Neo, Ery, Gen, Kan, Lin, Par, Rif, Str, and Tet indicate resistance to pleuromutilin, neomycin, erythromycin, gentamicin, kanamycin, lincomycin, paromomycin, rifampicin, streptomycin, and tetracycline, respectively. ${ }^{a}$ The strains with the highest titer of $r p o B$ and $r p s L$ mutation.

b The term "fold" was defined as the increased yield of the mutant strain compared to its parental strain, which was recalculated based on the cited articles. ${ }^{\mathrm{C}}$ The highest yield strain has no detected mutation within the $r p o B$ and rpsL gene.

Table 2. Summary of non-Streptomyces mutant effective for antibiotic overproduction.

\begin{tabular}{|c|c|c|c|c|c|}
\hline Antibiotic & Strain & Method & Mutation $^{\text {a }}$ & $($ Fold $) /(\mathrm{g} / \mathrm{L})^{\mathrm{b}}$ & Year/Ref. \\
\hline Bacilysin (25) & B. subtilis & Str, Rif & K56R L467P & $5-7(0.0166 \pm 0.0009)$ & $2015[54]$ \\
\hline \multirow{2}{*}{ Erythromycin (11) } & S. erythraea & Rif & S444F & $4(>1.5)$ & 2009 [55] \\
\hline & S. erythraea ${ }^{\mathrm{d}}$ & Rif & H437R & $4.0(0.163 \pm 0.034)$ & 2013 [32] \\
\hline \multirow{2}{*}{ FR900493 (22) } & B. cereus & Str & $-c$ & $7.2(0.55)$ & 1998 [33] \\
\hline & B. cereus & Gen & - & $2.7(0.22)$ & 2008 [34] \\
\hline GE2270 A (18) & P. rosea & Gen, Str, Rif & - & $1.8(-)$ & $2006[56]$ \\
\hline Norvancomycin & A. orientalis & Str, Rif, UV, HEE & - & $1.4(-)$ & 2006 [57] \\
\hline \multirow{2}{*}{ Pyrrolnitrin (29) } & P. pyrrocinia & Str & - & $10(0.015)$ & 1998 [33] \\
\hline & P.pyrrocinia & Gen & - & $5.3(0.008)$ & 2008 [34] \\
\hline Vancomycin (8) & A. orientalis & Rif & S442Y & $2.6-3.4(0.27 \pm 0.017)$ & 2013 [32] \\
\hline Violacein (24) & E. coli & Lin, Kan, HE & - & $41(-)$ & $2011[58]$ \\
\hline
\end{tabular}

a The strains with the highest titer of $r p o B$ and $r p s L$ mutation. ${ }^{\mathrm{b}}$ The term "fold" was defined as the increased yield of the mutant strain compared to its parental strain, which was recalculated based on the cited articles. ${ }^{c}$ The highest yield strain has no detected mutation within the rpoB and $r p s L$ gene. ${ }^{d}$ S. erythraea indicates Saccharopolyspora erythraea. 


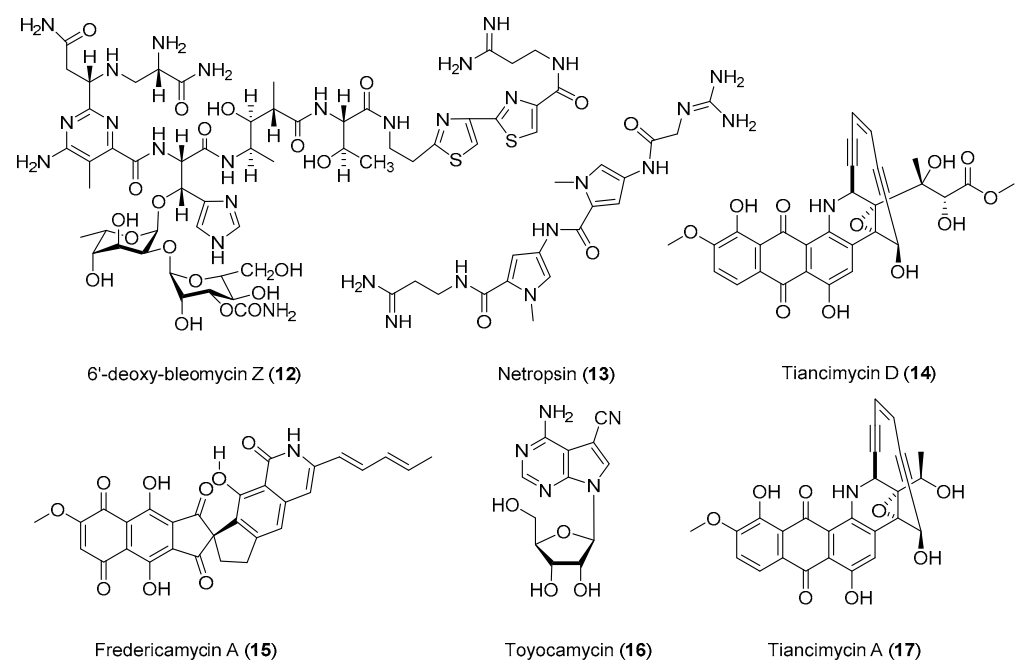

Figure 3. Representative structures of natural products with promising activities against tumor cells.

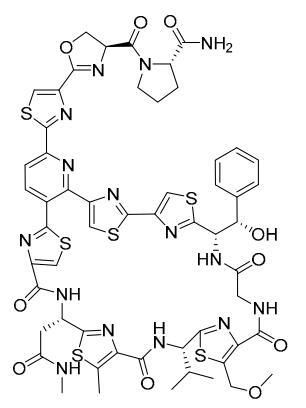

GE2270 A (18)

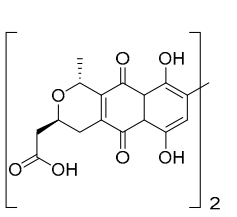

Actinorhodin (23)

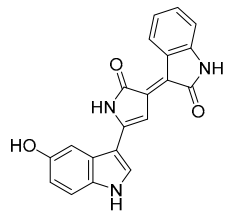

Violacein (24)

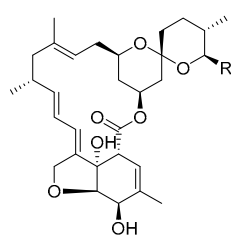

Milbemycin $\mathrm{A} 3: \mathrm{R}=\mathrm{CH}_{3}$ (19)
Milbemycin $\mathrm{A} 4: \mathrm{R}=\mathrm{C}_{2} \mathrm{H}_{5}(\mathbf{2 0})$
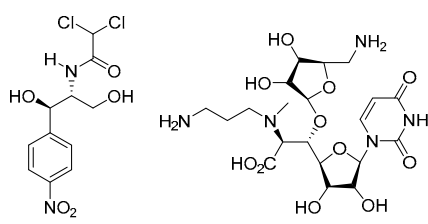

Chloramphenicol (21)

FR900493 (22)

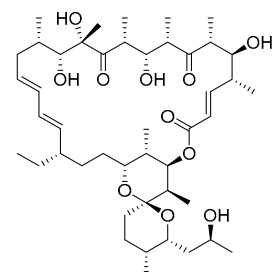

Bacilysin (25)

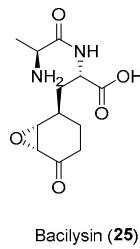

Rimocidin (30)

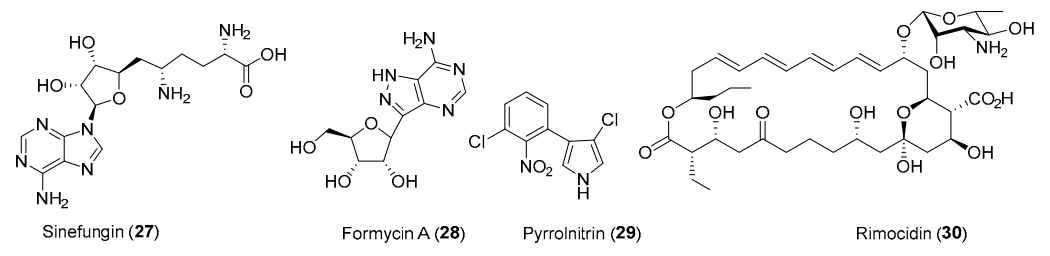

Figure 4. Representative natural products with antibacterial activities.

\subsection{Single Drug Resistance Mutation}

Act from S. coelicolor or its close relatives has been one of the model compounds for the study of the enzymology of bacterial type II polyketide synthases. Ochi et al. have used several antibiotics, such as streptomycin, paromycin, and erythromycin, to improve Act production (Table 1). For example, in a streptomycin-resistant (str) mutant with an rpsL R86P mutation in S. coelicolor 1147 (KO-944), the production of Act reached $133.8 \mathrm{mg} / \mathrm{L}$, at least a 55-fold increase over the parent strain [30]. Actinomycin D (9) (also named dactinomycin), isolated from Streptomyces parvullus, is a clinically used chromopeptide antineoplastic agent against trophoblastic neoplasms, testicular cancer, and several other cancers. In S. parvullus and Streptomyces antibioticus, several str, gentamycin-resistant (gen), or rifampicin-resistant (rif) mutants were obtained, which resulted in the multiple-fold increase of the yield of this important compound [32-34]. 
Enediynes are the most cytotoxic natural products known to date, and they are excellent payloads for antibody-drug conjugates against various cancers. Tiancimycins were recently discovered as 10-membered anthraquinone-type enediynes (Figure 3) [47]. The yield of tiancimycins in the wild-type Streptomyces sp. CB03234 was below $1 \mathrm{mg} / \mathrm{L}$, which significantly hampered preclinical studies using this strain. A rif strain CB03234-R-16 and a str strain CB03234-S were obtained by treating the S. sp. CB03234 wild-type strain with rifampicin or streptomycin [48,49]. The CB03234-R-16 has an rpoB L422P mutation, while CB03234-S has an rpsL K43N mutation. The yield of tiancimycin A (17) in CB03234-R-16 was $22.5 \pm 3.1 \mathrm{mg} / \mathrm{L}$ in shaking flasks and $13 \pm 1 \mathrm{mg} / \mathrm{L}$ in $15-\mathrm{L}$ fermentors. The yield of tiancimycin A (17) in CB03234-S reached $13.7 \pm 0.3 \mathrm{mg} / \mathrm{L}$ in 25-L fermentors. Interestingly CB03234-S produced tiancimycin D (14), an analog of tiancimycin A (17), with a decent yield of $19.2 \pm 0.4 \mathrm{mg} / \mathrm{L}$. The increase in the production of these promising anticancer drug leads would provide ample compounds for the future preclinical study.

\subsection{Combinations of Drug Resistance Mutation}

In S. coelicolor A3 (2), the str/gen or str/rif double mutants have a 1.7 to 2.5-fold higher ability to synthesize Act than the individual str, gen, or rif mutants [27,28]. Likewise, the str/gen/rif triple mutant and an octuple mutant C8 produced Act more than 48- or 180-fold higher than the wild-type strain, respectively [29]. Toyocamycin (16) is an important member of the nucleoside antibiotic family with diverse biological activities. As a promising antibiotic, it may have broad utility to control plant diseases. Yu and co-workers systematically increased the yield of toyocamycin (16) in Streptomyces diastatochromogenes 1628 by screening for rif or str/str/par mutants, which afforded strains 1628-T15 with an rpoB H437R mutationand SD3145 with a truncation mutation in RsmG [51]. The yield of toyocamycin (16) increased to 0.68 and $1.5 \mathrm{~g} / \mathrm{L}$ in strains 16228-T15 and SD3145, respectively. Salinomycin (6), a polyether antibiotic produced by Streptomyces albus, is used as a coccidiostat in chicken feed. It was recently shown to reduce epithelial cancer stem cells $>100$-fold over paclitaxel and is thus a usefuldrug lead against cancer stem cells [59]. The titer of salinomycin (6) was increased to $25 \mathrm{~g} / \mathrm{L}$ in a str/gen/rif triple mutant strain of $S$. albus KO606, a remarkable 2.3-fold increase relative to the starting industrial strain. This strain contains an rpsL K88N mutation, while no mutation was identified in ropB [45]. Similarly, the titer of a polyene macrolide rimocidin in S. rimosus increased over 4-fold compared with the wild-type strain, with $>0.6 \mathrm{~g} / \mathrm{L}$ in a 5-L fermentor [44].

\subsection{Combination of Traditional Mutagenesis and Ribosome Engineering}

Ribosome engineering was also frequently used in combination with traditional physical and chemical breeding methods to obtain mutants of higher yields. Sinefungin (27) is a nucleoside antibiotic with strong antifungal, antiviral, and anti-trypanosome activity. In Streptomyces incarnatus NRRL 8089, optimized UV-irradiation and rif screening resulted in a mutant strain, rif-400, with its production increased by 7-fold [46]. This strain has a single mutation A1340G in the rpoB gene, which corresponds to a D447G mutation. Bleomycins, glycopeptide antitumor antibiotics, are clinically used to treat various malignancies in combination chemotherapy. 6'-Deoxy-bleomycin $Z$ (12) is a novel bleomycin derivative discovered through combinatorial engineering of the BGCs of bleomycin and zorbamycin from Streptomyces verticillus ATCC 15003 and Streptomyces flavoviridis SB9001, respectively. By combined UV mutagenesis, antibiotic screening with gen, str, or rif, as well as fermentation optimization, a mutant strain S. flavoviridis G4F12 was obtained. It produced 12 with a titer above $70 \mathrm{mg} / \mathrm{L}$ under the optimized fermentation conditions, representing a 7-fold increase over its original production [53].

\subsection{Combination of Genome Shuffling and Ribosome Engineering}

Genome shuffling is an approach involving recursive genomic recombination within a population of phenotypically selected bacteria to generate new strain libraries, which may result in pronounced improvement in the screened phenotype. The combination of genome shuffling and ribosome engineering has been widely used in antibiotic development, including avilamycin (5) [36], daptomycin 
(7) [39], nosiheptide (1) [43], and virginiamycin (2) [52]. For example, avilamycin (5), a feed industry antimicrobial agent approved by the European Union, is used to inhibit the growth of multidrug resistant Gram-positive bacteria. Lv et al. [36] combined genome shuffling with str screening to obtain an improved recombinant strain Streptomyces viridochromogenes E-219. The yield of avilamycin in this strain reached $1.4 \mathrm{~g} / \mathrm{L}$, a 36.8 -fold increase in comparison with that of the ancestor $S$. viridochromogenes strain.

\subsection{Overexpression of Ribosome Recycling Factor}

At the end of protein translation in living cells, ribosome recycling factor encoded by the frr gene participates in ribosome recycling. Overexpression of frr in several Streptomyces strains led to increased production of Act, avermectins (3 and 4), and toyocamycin (16). By overexpressing the ribosome recycling factor in the avermectin producer, the yield of avermectin increased by 3-3.7 times to over $8 \mathrm{~g} / \mathrm{L} \mathrm{[35].} \mathrm{Similarly,} \mathrm{the} \mathrm{overexpression} \mathrm{of} \mathrm{a} \mathrm{ribosome} \mathrm{recycling} \mathrm{factor} \mathrm{also} \mathrm{increased} \mathrm{the} \mathrm{yield} \mathrm{of}$ toyocamycin (16) to about $0.6 \mathrm{~g} / \mathrm{L}$ due to the increased protein synthesis in the late-growth phase of the Streptomyces mycelium [50].

\subsection{The Application of Ribosome Engineering in Other Bacteria and Fungi}

Ribosome engineering has also been used in other bacterial species, including several Bacillus strains, Escherichia coli, and Paenibacillus agaridevorans, and in some fungi. For example, the introduction of three drug-resistance mutations in $r s m G, r p s L$, and $r p o B$ in $P$. agaridevorans markedly enhanced the productivity of cycloisomaltooligosaccharide glucanotransferase (CITase) by more than 1100-fold as compared to the wild-type strain [60]. Ahmetagic et al. [58] introduced lincomycin- and kanamycin-resistance into E. coli K12 AA23 pPSX-vioABCDE opv-1 to produce 41-fold higher expression of violacein (24). Finally, ribosome engineering is used not only to increase the production of secondary metabolites but also to increase the yield of $\alpha$-amylase [61], xylanase [62], vitamins [63], $\varepsilon$-poly-L-lysine [64-67], L-isoleucine [68], and fuels including butanol [69] and ethanol [70] (Table 3).

Table 3. Yield improvement of primary metabolites, proteins, and fuels by ribosome engineering.

\begin{tabular}{|c|c|c|c|c|c|}
\hline Miscellaneous Products & Strain & Method & Mutation $^{a}$ & Fold $/(\mathrm{g} / \mathrm{L})^{\mathrm{b}}$ & Year/Ref. \\
\hline CITase & P. agaridevorans & Str, Rif & K56R, R485H & $1100(1104 \pm 143 \mathrm{U} / \mathrm{mL})$ & 2018 [60] \\
\hline$\alpha$-Amylase & B. subtilis & Str & K56R & $1.5(4.0 \mathrm{U} / \mathrm{mL})$ & 2006 [61] \\
\hline Xylanase & S. viridochromogenes & Str & K88R & $1.14(>60 \mathrm{U} / \mathrm{mL})$ & 2013 [62] \\
\hline Vitamin B12 & P. shermanii & Rif, Gen, Ery & H437Y, H447R & $5.2(304 \pm 3 \mu \mathrm{g} / \mathrm{L} / \mathrm{OD} 600)$ & 2017 [63] \\
\hline \multirow{4}{*}{$\varepsilon$-poly-L-Lysine } & S. albulus & ARTP, Str, GS & $-c$ & $1.71(3.0)^{\mathrm{d}}$ & 2016 [64] \\
\hline & S. albulus & HT, Par & - & $1.45(2.59)$ & $2017[65]$ \\
\hline & S. albulus & Str, Gen, Rif & K108R & $1.75-2.39(3.83)$ & $2017[66]$ \\
\hline & S. albulus & Str & E85G & $1.79(3.04)$ & 2019 [67] \\
\hline L-Isoleucine & $\begin{array}{l}\text { Corynebacterium } \\
\text { glutamicum }\end{array}$ & $\begin{array}{l}\text { frr and fus } A \\
\text { Overexpression }\end{array}$ & - & $1.76(28.5)$ & 2015 [68] \\
\hline Butanol & $\begin{array}{c}\text { Clostridium } \\
\text { Saccharoperbutylacetonicum }\end{array}$ & Str & $\mathrm{K} 43 \mathrm{~N}$ & $1.6(16.5)$ & 2017 [69] \\
\hline Ethanol & K. variicola & Str & $\mathrm{K} 43 \mathrm{~N}$ & $1.3(34)$ & 2015 [70] \\
\hline
\end{tabular}

a The strains with the highest titer of rpoB and rpsL mutation. ${ }^{b}$ The term "fold" was defined as the increased yield of the mutant strain to its parental strain, which was recalculated based on the cited articles. ${ }^{c}$ The highest yield strain has no detected mutation within the rpoB and rpsL gene. ${ }^{\mathrm{d}}$ This is the highest yield of the $\varepsilon$-poly-L-lysine in shake flasks. CITase: cycloisomaltooligosaccharide glucanotransferase.

\section{Discovery of New Natural Products Using Ribosome Engineering}

Genome sequencing has revealed the vast potential to produce valuable secondary metabolites in Streptomyces. However, many BGCs are silent under standard fermentation conditions. Natural product synthesis in Streptomyces is affected by many factors, including nutrient supply including carbon and nitrogen sources, cofactors, the expression of functional biosynthetic enzymes, drug resistance, and export mechanisms. Many approaches have been used in activating silent BGCs [71,72], such as the 
"one strain many compounds" approach [73,74], cocultivation [75,76], manipulation of pleiotropic or pathway-specific regulators, genome mining [77,78], and BGC refactoring [17].

In 2009, Ochi and coworkers performed massive antibiotic-resistance screening on 1068 actinomycetes from soil, using rifampicin or streptomycin [79]. They discovered that $43 \%$ (51/119) of the nonantibiotic-producing Streptomyces strains from soil were able to commence antibacterial production. This could be due to the marked enhancement of previously undetectable antibiotic production or to triggering the biosynthesis of new antibiotics (Table 4). They subsequently isolated a series of novel macrocyclic piperidamycins (32-34) (Figure 5) from one soil strain Streptomyces mauvecolor with either a single H437L mutation in $r p o B$ or double mutation in $r p o B(\mathrm{H} 437 \mathrm{~L})$ and $r s p L$ (K88R). They proposed that the enhanced gene expression for piperidamycin biosynthesis in the mutants was due to the increased affinities of mutant RNA polymerases for their promoters, based on surface plasmon resonance analysis and in vitro synthesis of green fluorescent proteins.

Table 4. New natural products discovered through ribosome engineering.

\begin{tabular}{|c|c|c|c|c|c|}
\hline Natural Products & Strain & Method & Mutation $^{a}$ & Activity & Year/Ref. \\
\hline Neotrehalosadiamine (31) & B. subtilis & Rif & S487L & Antibacterial & $2004[80]$ \\
\hline Piperidamycins (32-34) & S. sp. 631689 & Rif, Str, Gen & K88R & Antibacterial & 2009 [79] \\
\hline$\gamma$-Actinorhodin (35) & S. coelicolor & Rif & $-\mathrm{b}$ & Antibacterial & 2013 [32] \\
\hline Mutaxanthenes (36-40) & $\begin{array}{l}\text { Nocardiaceae } \\
\text { FU40 } \Delta \text { ApoS8 }\end{array}$ & Rif, Str & - & - & 2013 [81] \\
\hline $41-46$ & $\begin{array}{l}\text { Aspergillus versicolo } \\
\text { ZBY-3 }\end{array}$ & $\mathrm{Neo}$ & - & Antitumor & 2014 [82] \\
\hline Inducamides A-C (47-49) & S. sp. SNC-109 & Rif & $\mathrm{X} 442 \mathrm{~F}$ & - & 2014 [83] \\
\hline $50-54$ & $\begin{array}{c}\text { Penicillium purpurogenum } \\
\text { G59 }\end{array}$ & Neo, DMSO & - & $\begin{array}{l}\text { Antibacterial } \\
\text { Antitumor }\end{array}$ & 2015 [84] \\
\hline Fredericamycin A (15) & $\begin{array}{c}\text { S. somaliensis SCSIO } \\
\text { ZH66 }\end{array}$ & Rif & $\mathrm{R} 447 \mathrm{H}$ & Antitumor & 2015 [41] \\
\hline 16 secondary metabolites & S. coelicolor & Rif, Str & - & Antibacterial & 2015 [85] \\
\hline $55-57$ & S. sp. SANK 60404 & Rif & H447D & - & $2016[86]$ \\
\hline 58,59 & S. sp. SoC090715LN-16 & Rif & H447Y & Antibacterial & 2018 [87] \\
\hline Cyclopentene derivatives & S. sp. HS-NF-1046R & Rif & - & - & 2019 [88] \\
\hline
\end{tabular}

Fredericamycin A (15) is a uniquely structured aromatic polyketide compound with excellent antitumor activity. Li et al. [41] identified the mutation of $\mathrm{R} 444 \mathrm{H}$ in rpoB of the resistant Streptomyces somaliensis ZH66-RIF1 using a rif screen with $300 \mu \mathrm{g} / \mathrm{mL}$ of rifampicin, which resulted in activating a previously silent gene cluster. After fermentation optimization, an optimized yield of $679.5 \pm 15.8 \mathrm{mg} / \mathrm{L}$ of $\mathbf{1 5}$ was obtained. MacMillan et al. isolated three new chlorinated alkaloids, inducamides A-C (47-49), from Streptomyces sp. SNC-109-M3, a rif mutant with a S442Y mutation in rpoB. Inducamides contain a 6-methylsalicylic acid unit and a tryptophan derivative, connected through an amide bond. Inducamide C (49) exhibited moderate cytotoxicity against NSCLC cell line HCC44 at $10 \mu \mathrm{M}$.

Kuzuyama et al. screened a total of 164 rif mutants among 11 actinomycetes and identified one mutant TW-R50-13 with an rpoB H437Y mutation [87]. Isolation of two overproduced metabolites in TW-R50-13 and their structural elucidation led to the discovery of three methylbenzene containing linear polyketides 55-57. Using the same approach, the authors screened a total of 114 rif mutants among 9 actinomycetes and identified one Streptomyces strain, S55-50-5, with the identical rpoB H437Y mutation [87]. This strain produced a novel isoindole-containing tetracyclic polyketide isoindolinomycin (58) with moderate cytotoxicity against the tested tumor cell lines and antibacterial activity against Staphylococcus aureus. 


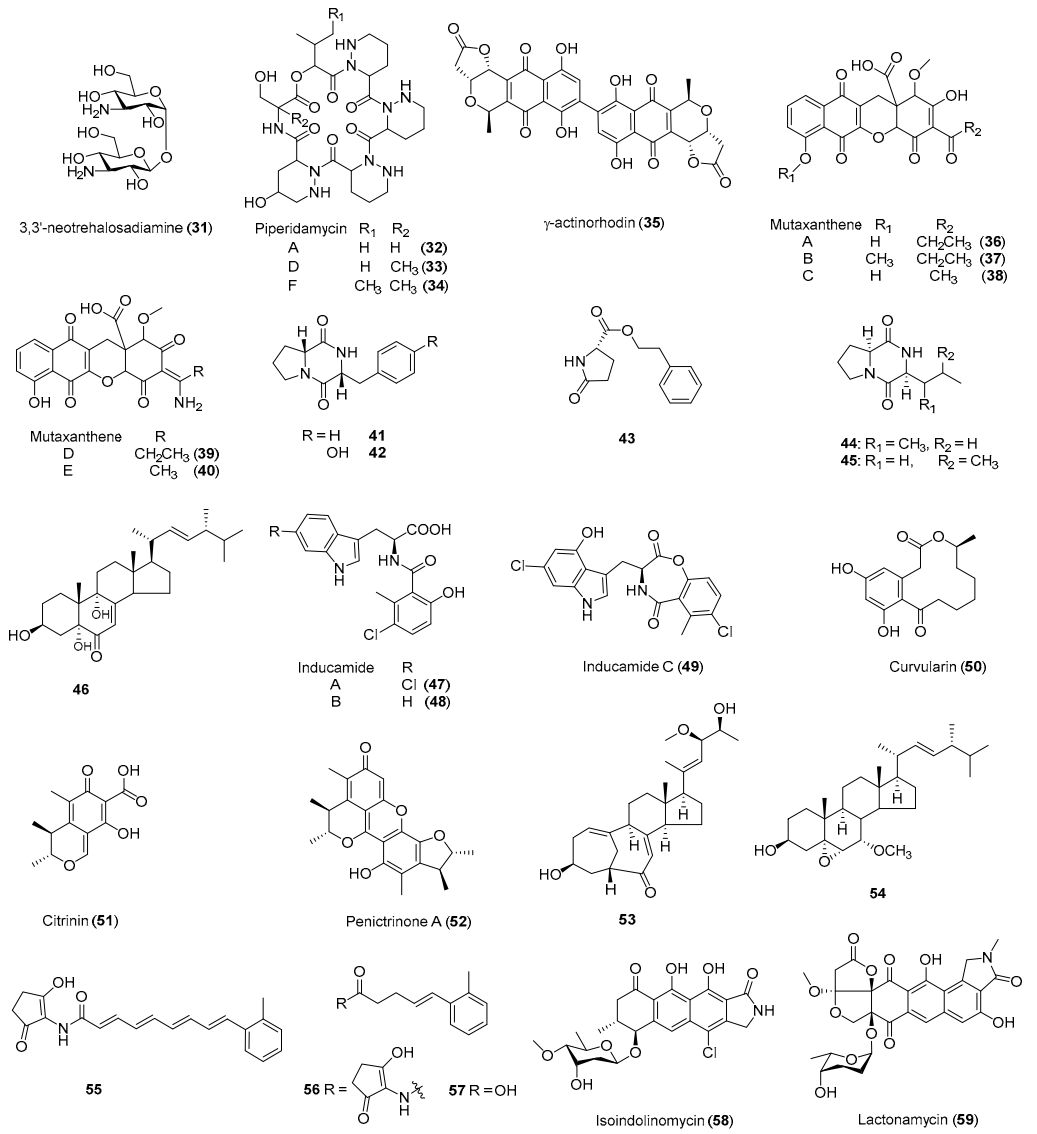

Figure 5. Representative natural products discovered by ribosome engineering.

In addition, ribosome engineering can also activate silent BGCs and discover new active compounds in other bacterial species or fungi. Ochi et al. [52] first introduced a rifamycin-induced $r p o B$ mutation into the $B$. subtilis strain, which led to the production of a new aminosaccharide antibiotic 3,3'-neotrehalosadiamine (31), for which production is silent in the wild-type strain. In a metabolomic phenotype screening of str or rif mutants in a rare actinomycete Nocardiopsis sp. FU40 $\triangle$ ApoS8, 311 unique metabolomic features were revealed by ultra-performance liquid chromatography ion-mobility mass spectrometry analysis [81]. This led to the isolation of five mutaxanthenes (36-40) with the unprecedented 12,12a-dihydro-1H-benzo(b)anthene-based scaffold in a rif mutant R4. Based on these data, Derewacz et al. suggested that activation of BGCs might be important cellular responses of certain antibiotic resistance mutations in the mutants [81]. Compounds extracted from fungi are an important source for new drug development $[89,90]$. By screening and isolation of neomycin-resistant mutants in marine-derived fungi, multiple active fungal natural products $41-46$ and $50-54$ were isolated from Aspergillus versicolor ZBY-3 or Penicillium purpurogenum G59, respectively [82,84].

\section{Possible Mechanism of Action of Ribosome Engineering}

Based on the above analysis, ribosome engineering has found a broad utility to increase the yields of many microbial metabolites and to facilitate discovery of new natural products in Streptomyces and many other microbes. These studies not only generate high yielding industrial strains to produce affordable therapeutics but also identify dozens of natural products with unprecedented structures and promising biological activities. Biosynthetic studies of these natural products yield novel insights for catalysis and enzymology. In this section, we discuss the possible mechanisms involved in ribosome engineering. 


\subsection{The Stringent Response, ppGpp, and Ribosome Engineering}

In 1969, Cashel and Gallant first observed the presence of guanosine 5' -diphosphate $3^{\prime}$-diphosphate ppGpp, the signaling molecule of the stringent response, in starved E. coli [91]. The cellular centration of ppGpp is normally relatively low. Once stimulated by environmental stress such as nutrient starvation, its massive accumulation triggers an emergency response in cells. Since ppGpp was found to bind to RNA polymerases, Ochi et al. suggested that the RNA polymerases with certain mutations on rpoB may mimic the RNA polymerase bound with ppGpp in the wild-type S. coelicolor A3(2) [28]. The relA gene encodes the bifunctional (p)ppGpp synthase/hydrolase, while relC gene encodes the 50S ribosomal protein L11. In relA- or relC-knockout $S$. coelicolor A3(2) mutant strains, incapable of producing ppGpp and Act $(<0.03$ in OD633), they identified more than a dozen rif mutants with mutations in rpoB that produced higher levels of Act than the wild-type strains M400 and 1147, respectively (0.43 or 1.71 in OD633). Similarly, a relC-knockout mutant of S. lividans 1326 lost the ability to produce ppGpp and Act, while rif mutants with certain mutations in rpoB could restore Act production [92]. Actinomadura sp. ATCC 39727 (renamed as Nonomuraea sp. strain 39 727) contains duplicated rpoB alleles, in which one $r p o B, \mathrm{rpoB}^{\mathrm{R}}$, harbored the $\mathrm{H} 426 \mathrm{~N}$ missense mutation [93]. The fact that the production of the glycopeptide antibiotic A40926 in Nonomuraea. sp. ATCC 39727 was not controlled by the stringent response and the presence of $r p o B$ gene polymorphism in 5 out of 75 rare actinomycetes [94] is consistent with the proposal that certain rif mutants may mimic the stringent response. In $S$. mauvecolor, Ochi et al. further showed that the mutant RNA polymerases isolated from stationary-phase cells have enhanced affinity towards three $S$. coelicolor promoters ACTII-ORF4p, SIGNp1, and SIGNp2 in vitro [79]. Structure studies of the binding between these mutant RNA polymerases and promoters would provide further insights into these important interactions [95].

\subsection{Ribosome Stability, Recycling, and Streptomycin-Resistance}

Str mutants may confer high or low levels of streptomycin resistance. High-level streptomycin resistance (Minimum inhibitory concentration (MIC) $>100 \mu \mathrm{g} / \mathrm{mL}$ ) may often result from K88E or K88R mutations in the ribosomal protein S12. In a salinomycin (6) producing industrial strain of $S$. albus, Ochi et al. observed that the mutant strain KO-600 (K88R) exhibited more than 3-fold enhanced protein synthesis activity during the stationary phase than the parental strain SAM-X, using an in vitro ribosome translation assay [45]. In addition, the K88R mutant ribosome appeared to be more stable than the wild-type ribosome in the presence of $0.8 \mathrm{mM} \mathrm{Mg}^{2+}$. In S. coelicolor $\mathrm{A} 3(2)$, the K88E and P91S mutant ribosome also showed enhanced protein synthesis activity and could form a more stable $70 S$ complex [96]. In addition, Ochi and coworkers simultaneously observed the overproduction of Act and increased expression of ribosome recycling factor in a strain of S. coelicolor with the K88E mutation in its S12 ribosomal protein [97]. They further demonstrated that overexpression of the frr gene encoding RRF in an S. coelicolor wild-type strain yielded higher protein synthesis rate and Act titer. Therefore, the increased translation in str mutants may significantly contribute to the observed titer increase.

\subsection{Sublethal Concentrations of Different Antibiotics and Ribosome Engineering}

Sublethal concentrations of different antibiotics, including lincomycin, streptomycin, erythromycin, have been used to induce the production of antibiotics. In a 1996 study, tetracycline, streptomycin, and hygromycin were able to induce Act production in S. lividans TK21 [15]. The maximum Act induction was observed when 10 or $15 \mu \mathrm{g} / \mathrm{mL}$ tetracycline or streptomycin was added to the cultures. At these concentrations, the growth of $S$. lividans was only slightly affected. In contrast, other tested antibiotics, including chloramphenicol, erythromycin, lincomycin, kanamycin, spectinomycin, fusidic acid, thiopeptin, thiostrepton, rifamycin, puromycin, ampicilin, and decoyinine, were unable to induce Act production. Interestingly, Ochi and coworkers also showed that lincomycin at subinhibitory concentrations (1/10 of the MIC of $S$. coelicolor A3(2)) increased Act overproduction by overexpression of the pathway-specific regulatory gene actII-ORF4 in S. coelicolor A3(2). Lincomycin (1/2 or 1/3 of the 
MIC of S. lividans 1326) could also lead to the production of novel congeners of calcium-dependent antibiotics in S. lividans 1326 [98]. At sublethal concentrations, these antibiotics might serve as the language to facilitate communication among the bacterial species [99]. It might be interesting to study the intrinsic relationship between antibiotic language and ribosome engineering. One hypothesis could be that the presence of these antibiotic stimuli in the natural environments might lead to the accumulation of spontaneous mutants, which were subsequently discovered using the ribosome engineering approach.

\section{Conclusions}

To discover the next generation of medicines, the exploration of the biosynthetic potential in Streptomyces or other bacteria would require dedication, technology advancement, and intensive efforts. In the post-genomic era, many newly developed technologies have enabled the discovery of natural products from microbes or improvement of their production. Ribosome engineering remains a cost-effective way to discover new natural products and to enhance the titers of promising natural products, proteins, or biofuels in the engineered strains. The combination of ribosome engineering and other methods, such as genome shuffling, will be more effective to accelerate its development, especially for the development of high-yield industrial strains to produce natural products or other useful products. For example, ribosome engineering has only been used to improve the yield of a few industrial producing strains for the production of avermectins $(3,4)$, salinomycin $(6)$, vancomycin $(8)$, and GE2270 (18). In addition, ribosome engineering could identify many useful mutant strains by the screening of a variety of antibiotics. The detailed mechanism of action of ribosome engineering in these mutants would need to be further elucidated. For example, structure studies of the interactions of the mutated RNA polymerases and their respective promoters would increase our understanding of the precise mechanisms of gene expression control. In the future, researchers may be able to activate certain BGCs or to improve the production of designed natural products in a more specific manner using ribosome engineering.

Author Contributions: S.Z., Y.D., and Y.H. wrote the manuscript.

Funding: This work was supported by NSFC grants 81473124 (to Y.H.) and 81530092 (to Y.D.) and the Chinese Ministry of Education 111 Project B0803420 (to Y.D.).

Conflicts of Interest: The authors declare no conflict of interest.

\section{References}

1. Demain, A.L.; Sánchez, S. Microbial drug discovery: 80 years of progress. J. Antibiot. 2009, 62, 5-16. [CrossRef] [PubMed]

2. Shen, B. A new golden age of natural products drug discovery. Cell 2015, 163, 1297-1300. [CrossRef] [PubMed]

3. Liu, R.; Deng, Z.; Liu, T. Streptomyces species: Ideal chassis for natural product discovery and overproduction. Metab. Eng. 2018, 50, 74-84. [CrossRef] [PubMed]

4. Weber, T.; Charusanti, P.; Musiol-Kroll, E.M.; Jiang, X.; Tong, Y.; Kim, H.U.; Lee, S.Y. Metabolic engineering of antibiotic factories: New tools for antibiotic production in actinomycetes. Trends Biotechnol. 2015, 33, 15-26. [CrossRef] [PubMed]

5. Heitman, J.; Movva, N.; Hall, M. Targets for cell cycle arrest by the immunosuppressant rapamycin in yeast. Science 1991, 253, 905-909. [CrossRef] [PubMed]

6. Saxton, R.A.; Sabatini, D.M. mTOR signaling in growth, metabolism, and disease. Cell 2017, 169, 361-371. [CrossRef] [PubMed]

7. Benjamin, D.; Colombi, M.; Moroni, C.; Hall, M.N. Rapamycin passes the torch: A new generation of mTOR inhibitors. Nat. Rev. Drug Discov. 2011, 10, 868-880. [CrossRef] [PubMed]

8. Guo, Z.; Hong, S.Y.; Wang, J.; Rehan, S.; Liu, W.; Peng, H.; Das, M.; Li, W.; Bhat, S.; Peiffer, B.; et al. Rapamycin-inspired macrocycles with new target specificity. Nat. Chem. 2019, 11, 254-263. [CrossRef] [PubMed] 
9. Ikeda, H.; Ishikawa, J.; Hanamoto, A.; Shinose, M.; Kikuchi, H.; Shiba, T.; Sakaki, Y.; Hattori, M.; Ōmura, S. Complete genome sequence and comparative analysis of the industrial microorganism Streptomyces avermitilis. Nat. Biotechnol. 2003, 21, 526-531. [CrossRef] [PubMed]

10. Bentley, S.D.; Chater, K.F.; Cerdeño-Tárraga, A.M.; Challis, G.L.; Thomson, N.R.; James, K.D.; Harris, D.E.; Quail, M.A.; Kieser, H.; Harper, D.; et al. Complete genome sequence of the model actinomycete Streptomyces coelicolor A3(2). Nature 2002, 417, 141-147. [CrossRef]

11. Yan, X.; Chen, J.-J.; Adhikari, A.; Yang, D.; Crnovcic, I.; Wang, N.; Chang, C.-Y.; Rader, C.; Shen, B. Genome mining of Micromonospora yangpuensis DSM 45577 as a producer of an anthraquinone-fused enediyne. Org. Lett. 2017, 19, 6192-6195. [CrossRef] [PubMed]

12. Rudolf, J.D.; Yan, X.; Shen, B. Genome neighborhood network reveals insights into enediyne biosynthesis and facilitates prediction and prioritization for discovery. J. Ind. Microbiol. Biotechnol. 2016, 43, 261-276. [CrossRef] [PubMed]

13. Pan, G.; Xu, Z.; Guo, Z.; Hindra; Ma, M.; Yang, D.; Zhou, H.; Gansemans, Y.; Zhu, X.; Huang, Y.; et al. Discovery of the leinamycin family of natural products by mining actinobacterial genomes. Proc. Natl. Acad. Sci. USA 2017, 114, E11131-E11140. [CrossRef] [PubMed]

14. Essential Medicines. Available online: http://www.who.int/topics/essential_medicines (accessed on 28 July 2019).

15. Shima, J.; Hesketh, A.; Okamoto, S.; Kawamoto, S.; Ochi, K. Induction of actinorhodin production by rpsL (encoding ribosomal protein S12) mutations that confer streptomycin resistance in Streptomyces lividans and Streptomyces coelicolor A3(2). J. Bacteriol. 1996, 178, 7276-7284. [CrossRef] [PubMed]

16. Ochi, K. Insights into microbial cryptic gene activation and strain improvement: Principle, application and technical aspects. J. Antibiot. 2017, 70, 25-40. [CrossRef] [PubMed]

17. Smanski, M.J.; Zhou, H.; Claesen, J.; Shen, B.; Fischbach, M.A.; Voigt, C.A. Synthetic biology to access and expand nature's chemical diversity. Nat. Rev. Genet. 2016, 14, 135-149. [CrossRef]

18. Nielsen, J.; Keasling, J.D. Engineering cellular metabolism. Cell 2016, 164, 1185-1197. [CrossRef]

19. Bose, J.L. Chemical and UV mutagenesis. Methods Mol. Biol. 2016, 1373, 111-115.

20. Gong, J.; Zheng, H.; Wu, Z.; Chen, T.; Zhao, X. Genome shuffling: Progress and applications for phenotype improvement. Biotechnol. Adv. 2009, 27, 996-1005. [CrossRef]

21. Magocha, T.A.; Zabed, H.; Yang, M.; Yun, J.; Zhang, H.; Qi, X. Improvement of industrially important microbial strains by genome shuffling: Current status and future prospects. Bioresour. Technol. 2018, 257, 281-289. [CrossRef]

22. Xu, M.; Wright, G.D. Heterologous expression-facilitated natural products' discovery in actinomycetes. J. Ind. Microbiol. Biotechnol. 2018, 46, 415-431. [CrossRef] [PubMed]

23. Jeschek, M.; Gerngross, D.; Panke, S. Combinatorial pathway optimization for streamlined metabolic engineering. Curr. Opin. Biotechnol. 2017, 47, 142-151. [CrossRef] [PubMed]

24. Gibson, D.G.; Glass, J.I.; Lartigue, C.; Noskov, V.N.; Chuang, R.-Y.; Algire, M.A.; Benders, G.A.; Montague, M.G.; Ma, L.; Moodie, M.M.; et al. Creation of a bacterial cell controlled by a chemically synthesized genome. Science 2010, 329, 52-56. [CrossRef] [PubMed]

25. Hesketh, A.; Ochi, K. A novel method for improving Streptomyces coelicolor A3(2) for production of actinorhodin by introduction of rpsL (encoding ribosomal protein S12) mutations conferring resistance to streptomycin. J. Antibiot. 1997, 50, 532-535. [CrossRef] [PubMed]

26. Okamoto-Hosoya, Y.; Sato, T.-A.; Ochi, K. Resistance to paromomycin is conferred by rpsL mutations, accompanied by an enhanced antibiotic production in Streptomyces coelicolor A3(2). J. Antibiot. 2000, 53, 1424-1427. [CrossRef] [PubMed]

27. $\mathrm{Hu}, \mathrm{H} . ; \mathrm{Ochi}, \mathrm{K}$. Novel approach for improving the productivity of antibiotic-producing strains by inducing combined resistant mutations. Appl. Environ. Microbiol. 2001, 67, 1885-1892. [CrossRef]

28. Xu, J.; Tozawa, Y.; Lai, C.; Hayashi, H.; Ochi, K. A rifampicin resistance mutation in the rpoB gene confers ppGpp-independent antibiotic production in Streptomyces coelicolor A3(2). Mol. Genet. Genom. 2002, 268, 179-189. [CrossRef]

29. Wang, G.; Hosaka, T.; Ochi, K. Dramatic activation of antibiotic production in Streptomyces coelicolor by cumulative drug resistance mutations. Appl. Environ. Microbiol. 2008, 74, 2834-2840. [CrossRef] [PubMed] 
30. Tanaka, Y.; Komatsu, M.; Okamoto, S.; Tokuyama, S.; Kaji, A.; Ikeda, H.; Ochi, K. Antibiotic overproduction by rpsL and $r s m G$ mutants of various actinomycetes. Appl. Environ. Microbiol. 2009, 75, 4919-4922. [CrossRef] [PubMed]

31. Imai, Y.; Fujiwara, T.; Ochi, K.; Hosaka, T. Development of the ability to produce secondary metabolites in Streptomyces through the acquisition of erythromycin resistance. J. Antibiot. 2012, 65, 323-326. [CrossRef]

32. Tanaka, Y.; Kasahara, K.; Hirose, Y.; Murakami, K.; Kugimiya, R.; Ochi, K. Activation and products of the cryptic secondary metabolite biosynthetic gene clusters by rifampin resistance ( $r p o B)$ mutations in actinomycetes. J. Bacteriol. 2013, 195, 2959-2970. [CrossRef]

33. Hosoya, Y.; Okamoto, S.; Muramatsu, H.; Ochi, K. Acquisition of certain streptomycin-resistant (str) mutations enhances antibiotic production in bacteria. Antimicrob. Agents Chemother. 1998, 42, 2041-2047. [CrossRef] [PubMed]

34. Hu, H.-F.; Zhang, Q.; Zhu, B.-Q. Enhanced antibiotic production by inducing low level of resistance to gentamicin. Chin. J. Nat. Med. 2008, 6, 146-152. [CrossRef]

35. Li, L.; Guo, J.; Wen, Y.; Chen, Z.; Song, Y.; Li, J. Overexpression of ribosome recycling factor causes increased production of avermectin in Streptomyces avermitilis strains. J. Ind. Microbiol. Biotechnol. 2010, 37, 673-679. [CrossRef]

36. Lv, X.A.; Jin, Y.Y.; Li, Y.D.; Zhang, H.; Liang, X.L. Genome shuffling of Streptomyces viridochromogenes for improved production of avilamycin. Appl. Microbiol. Biotechnol. 2013, 97, 641-648. [CrossRef]

37. Gomez-Escribano, J.P.; Bibb, M.J. Engineering Streptomyces coelicolor for heterologous expression of secondary metabolite gene clusters. Microb. Biotechnol. 2011, 4, 207-215. [CrossRef] [PubMed]

38. Li, L.; Ma, T.; Liu, Q.; Huang, Y.; Hu, C.; Liao, G. Improvement of daptomycin production in Streptomyces roseosporus through the acquisition of pleuromutilin resistance. BioMed. Res. Int. 2013, 2013, 1-6.

39. Yu, G.; Hui, M.; Li, R.; Chen, L.; Tian, H.; Wang, L. Enhancement of daptomycin production by the method of combining ribosome engineering and genome shuffling in Streptomyces roseosporus. Appl. Biochem. Microbiol. 2018, 54, 611-615. [CrossRef]

40. Wang, L.; Zhao, Y.; Liu, Q.; Huang, Y.; Hu, C.; Liao, G. Improvement of A21978C production in Streptomyces roseosporus by reporter-guided rpsL mutation selection. J. Appl. Microbiol. 2012, 112, 1095-1101. [CrossRef]

41. Zhang, Y.; Huang, H.; Xu, S.; Wang, B.; Ju, J.; Tan, H.; Li, W. Activation and enhancement of fredericamycin A production in deep sea-derived Streptomyces somaliensis SCSIO ZH66 by using ribosome engineering and response surface methodology. Microb. Cell Factories 2015, 14, 1039. [CrossRef] [PubMed]

42. Wang, X.-J.; Wang, X.-C.; Xiang, W.-S. Improvement of milbemycin-producing Streptomyces bingchenggensis by rational screening of ultraviolet- and chemically induced mutants. World J. Microbiol. Biotechnol. 2009, 25, 1051-1056. [CrossRef]

43. Wang, Q.; Zhang, D.; Li, Y.; Zhang, F.; Wang, C.; Liang, X. Genome shuffling and ribosome engineering of Streptomyces actuosus for high-yield nosiheptide production. Appl. Biochem. Biotechnol. 2014, 173, 1553-1563. [CrossRef]

44. Zhao, Y.; Song, Z.; Ma, Z.; Bechthold, A.; Yu, X. Sequential improvement of rimocidin production in Streptomyces rimosus M527 by introduction of cumulative drug-resistance mutations. J. Ind. Microbiol. Biotechnol. 2019, 46, 697-708. [CrossRef]

45. Tamehiro, N.; Hosaka, T.; Xu, J.; Hu, H.; Otake, N.; Ochi, K. Innovative approach for improvement of an antibiotic-overproducing industrial strain of Streptomyces albus. Appl. Environ. Microbiol. 2003, 69, 6412-6417. [CrossRef]

46. Fukuda, K.; Tamura, T.; Ito, H.; Yamamoto, S.; Ochi, K.; Inagaki, K. Production improvement of antifungal, antitrypanosomal nucleoside sinefungin by rроB mutation and optimization of resting cell system of Streptomyces incarnatus NRRL 8089. J. Biosci. Bioeng. 2010, 109, 459-465. [CrossRef]

47. Yan, X.; Ge, H.; Huang, T.; Hindra; Yang, D.; Teng, Q.; Crnovčić, I.; Li, X.; Rudolf, J.D.; Lohman, J.R.; et al. Strain prioritization and genome mining for enediyne natural products. mBio 2016, 7, 02104-02116. [CrossRef] [PubMed]

48. Liu, L.; Pan, J.; Wang, Z.; Yan, X.; Yang, D.; Zhu, X.; Shen, B.; Duan, Y.; Huang, Y. Ribosome engineering and fermentation optimization leads to overproduction of tiancimycin A, a new enediyne natural product from Streptomyces sp. CB03234. J. Ind. Microbiol. Biotechnol. 2018, 45, 141-151. [CrossRef] [PubMed] 
49. Zhuang, Z.; Jiang, C.; Zhang, F.; Huang, R.; Yi, L.; Huang, Y.; Yan, X.; Duan, Y.; Zhu, X. Streptomycin-induced ribosome engineering complemented with fermentation optimization for enhanced production of 10-membered enediynes tiancimycin-A and tiancimycin-D. Biotechnol. Bioeng. 2019, 116, 1304-1314. [CrossRef] [PubMed]

50. Ma, Z.; Tao, L.; Bechthold, A.; Shentu, X.; Bian, Y.; Yu, X. Overexpression of ribosome recycling factor is responsible for improvement of nucleotide antibiotic-toyocamycin in Streptomyces diastatochromogenes 1628. Appl. Microbiol. Biotechnol. 2014, 98, 5051-5058. [CrossRef]

51. Ma, Z.; Luo, S.; Xu, X.; Bechthold, A.; Yu, X. Characterization of representative rpoB gene mutations leading to a significant change in toyocamycin production of Streptomyces diastatochromogenes 1628. J. Ind. Microbiol. Biotechnol. 2016, 43, 463-471. [CrossRef]

52. Tong, Q.-Q.; Zhou, Y.-H.; Chen, X.-S.; Wu, J.-Y.; Wei, P.; Yuan, L.-X.; Yao, J.-M. Genome shuffling and ribosome engineering of Streptomyces virginiae for improved virginiamycin production. Bioprocess Biosyst. Eng. 2018, 41, 729-738. [CrossRef] [PubMed]

53. Zhu, X.; Kong, J.; Yang, H.; Huang, R.; Huang, Y.; Yang, D.; Shen, B.; Duan, Y. Strain improvement by combined UV mutagenesis and ribosome engineering and subsequent fermentation optimization for enhanced 6'-deoxy-bleomycin Z production. Appl. Microbiol. Biotechnol. 2018, 102, 1651-1661. [CrossRef] [PubMed]

54. Gupta, P.B.; Onder, T.T.; Jiang, G.; Tao, K.; Kuperwasser, C.; Weinberg, R.A.; Lander, E.S. Identification of selective inhibitors of cancer stem cells by high-throughput screening. Cell 2009, 138, 645-659. [CrossRef] [PubMed]

55. Tojo, S.; Tanaka, Y.; Ochi, K. Activation of antibiotic production in Bacillus spp. by cumulative drug resistance mutations. Antimicrob. Agents Chemother. 2015, 59, 7799-7804. [CrossRef] [PubMed]

56. Carata, E.; Peano, C.; Tredici, S.M.; Ferrari, F.; Tala, A.; Corti, G.; Bicciato, S.; De Bellis, G.; Alifano, P. Phenotypes and gene expression profiles of Saccharopolyspora erythraea rifampicin-resistant (rif) mutants affected in erythromycin production. Microb Cell Fact 2009, 8, 18. [CrossRef] [PubMed]

57. Beltrametti, F.; Rossi, R.; Selva, E.; Marinelli, F. Antibiotic production improvement in the rare actinomycete Planobispora rosea by selection of mutants resistant to the aminoglycosides streptomycin and gentamycin and to rifamycin. J. Ind. Microbiol. Biotechnol. 2006, 33, 283-288. [CrossRef] [PubMed]

58. Wang, Y.; Liu, Y.; Zhu, Y.; Liu, S.; Cai, C.; Xu, P. Screening of high yield norvancomycin producing strain by streptomycin and rifampicin resistant mutation. Chin. J. Antibiot. 2006, 31, 243-246.

59. Ahmetagic, A.; Pemberton, J.M. Antibiotic resistant mutants of Escherichia coli K12 show increases in heterologous gene expression. Plasmid 2011, 65, 51-57. [CrossRef] [PubMed]

60. Funane, K.; Tanaka, Y.; Hosaka, T.; Murakami, K.; Miyazaki, T.; Shiwa, Y.; Gibu, S.; Inaoka, T.; Kasahara, K.; Fujita, N.; et al. Combined drug resistance mutations substantially enhance enzyme production in Paenibacillus agaridevorans. J. Bacteriol. 2018, 200, JB.00188-18. [CrossRef]

61. Kurosawa, K.; Hosaka, T.; Tamehiro, N.; Inaoka, T.; Ochi, K. Improvement of alpha-amylase production by modulation of ribosomal component protein $\mathrm{S} 12$ in Bacillus subtilis 168. Appl. Environ. Microbiol. 2006, 72, 71-77. [CrossRef]

62. Liu, Z.; Zhao, X.; Bai, F. Production of xylanase by an alkaline-tolerant marine-derived Streptomyces viridochromogenes strain and improvement by ribosome engineering. Appl. Microbiol. Biotechnol. 2013, 97, 4361-4368. [CrossRef] [PubMed]

63. Tanaka, Y.; Kasahara, K.; Izawa, M.; Ochi, K. Applicability of ribosome engineering to vitamin B12 production by Propionibacterium shermanii. Biosci. Biotechnol. Biochem. 2017, 81, 1636-1641. [CrossRef] [PubMed]

64. Zheng, G.; Wang, L.; Gao, Y.; Xiang, J.; Chen, X.; Mao, Z. Breeding and fermentation performance of a high-yield $\varepsilon$-poly-L-lysine producing strain. Acta Microbiol. Sin. 2016, 56, 1450-1458.

65. Liu, Y.-J.; Chen, X.-S.; Zhao, J.-J.; Pan, L.; Mao, Z.-G. Development of microtiter plate culture method for rapid screening of $\varepsilon$-Poly-L-lysine-producing strains. Appl. Biochem. Biotechnol. 2017, 183, 1209-1223. [CrossRef] [PubMed]

66. Wang, L.; Chen, X.; Wu, G.; Li, S.; Zeng, X.; Ren, X.; Tang, L.; Mao, Z. Enhanced $\varepsilon$-poly-L-lysine production by inducing double antibiotic-resistant mutations in Streptomyces albulus. Bioprocess Biosyst. Eng. 2017, 40, 271-283. [CrossRef] [PubMed]

67. Liu, Y.; Chen, X.; Zhao, J.; Li, Q.; Mao, Z. Improvement of $\varepsilon$-poly-L-lysine production of Streptomyces albulus by continuous introduction of streptomycin resistance. Process. Biochem. 2019, 82, 10-18. [CrossRef] 
68. Zhao, J.; Hu, X.; Li, Y.; Wang, X. Overexpression of ribosome elongation factor $\mathrm{G}$ and recycling factor increases L-isoleucine production in Corynebacterium glutamicum. Appl. Microbiol. Biotechnol. 2015, 99, 4795-4805. [CrossRef] [PubMed]

69. Tanaka, Y.; Kasahara, K.; Hirose, Y.; Morimoto, Y.; Izawa, M.; Ochi, K. Enhancement of butanol production by sequential introduction of mutations conferring butanol tolerance and streptomycin resistance. J. Biosci. Bioeng. 2017, 124, 400-407. [CrossRef]

70. Suzuki, T.; Seta, K.; Nishikawa, C.; Hara, E.; Shigeno, T.; Nakajima-Kambe, T. Improved ethanol tolerance and ethanol production from glycerol in a streptomycin-resistant Klebsiella variicola mutant obtained by ribosome engineering. Bioresour. Technol. 2015, 176, 156-162. [CrossRef]

71. Ochi, K.; Hosaka, T. New strategies for drug discovery: Activation of silent or weakly expressed microbial gene clusters. Appl. Microbiol. Biotechnol. 2013, 97, 87-98. [CrossRef]

72. Rutledge, P.J.; Challis, G.L. Discovery of microbial natural products by activation of silent biosynthetic gene clusters. Nat. Rev. Genet. 2015, 13, 509-523. [CrossRef] [PubMed]

73. Romano, S.; Jackson, S.A.; Patry, S.; Dobson, A.D.W. Extending the "one strain many compounds" (OSMAC) principle to marine microorganisms. Mar. Drugs 2018, 16, 244. [CrossRef] [PubMed]

74. Bode, H.B.; Bethe, B.; Höfs, R.; Zeeck, A. Big effects from small changes: Possible ways to explore nature's chemical diversity. ChemBioChem 2002, 3, 619-627. [CrossRef]

75. Okada, B.K.; Seyedsayamdost, M.R. Antibiotic dialogues: Induction of silent biosynthetic gene clusters by exogenous small molecules. FEMS Microbiol. Rev. 2017, 41, 19-33. [CrossRef] [PubMed]

76. Ueda, K.; Beppu, T. Antibiotics in microbial coculture. J. Antibiot. 2017, 70, 361-365. [CrossRef] [PubMed]

77. Sandiford, S.K. Genome database mining for the discovery of novel lantibiotics. Expert Opin. Drug Discov. 2017, 12, 489-495. [CrossRef] [PubMed]

78. Kang, H.-S. Phylogeny-guided (meta)genome mining approach for the targeted discovery of new microbial natural products. J. Ind. Microbiol. Biotechnol. 2016, 44, 285-293. [CrossRef]

79. Hosaka, T.; Ohnishi-Kameyama, M.; Muramatsu, H.; Murakami, K.; Tsurumi, Y.; Kodani, S.; Yoshida, M.; Fujie, A.; Ochi, K. Antibacterial discovery in actinomycetes strains with mutations in RNA polymerase or ribosomal protein S12. Nat. Biotechnol. 2009, 27, 462-464. [CrossRef]

80. Inaoka, T.; Takahashi, K.; Yada, H.; Yoshida, M.; Ochi, K. RNA polymerase mutation activates the production of a dormant antibiotic 3,3'-neotrehalosadiamine via an autoinduction mechanism in Bacillus subtilis. J. Biol. Chem. 2004, 279, 3885-3892. [CrossRef]

81. Derewacz, D.K.; Goodwin, C.R.; McNees, C.R.; McLean, J.A.; Bachmann, B.O. Antimicrobial drug resistance affects broad changes in metabolomic phenotype in addition to secondary metabolism. Proc. Natl. Acad. Sci. USA 2013, 110, 2336-2341. [CrossRef]

82. Dong, Y.; Cui, C.-B.; Li, C.-W.; Hua, W.; Wu, C.-J.; Zhu, T.-J.; Gu, Q.-Q. Activation of dormant secondary metabolite production by introducing neomycin resistance into the deep-sea fungus, Aspergillus versicolor ZBY-3. Mar. Drugs 2014, 12, 4326-4352. [CrossRef] [PubMed]

83. Fu, P.; Jamison, M.; La, S.; Macmillan, J.B. Inducamides A-C, chlorinated alkaloids from an RNA polymerase mutant strain of Streptomyces sp. Org. Lett. 2014, 16, 5656-5659. [CrossRef] [PubMed]

84. Wu, C.-J.; Yi, L.; Cui, C.-B.; Li, C.-W.; Wang, N.; Han, X. Activation of the silent secondary metabolite production by introducing neomycin-resistance in a marine-derived Penicillium purpurogenum G59. Mar. Drugs 2015, 13, 2465-2487. [CrossRef] [PubMed]

85. Derewacz, D.K.; Covington, B.C.; McLean, J.A.; Bachmann, B.O. Mapping microbial response metabolomes for induced natural product discovery. ACS Chem. Boil. 2015, 10, 1998-2006. [CrossRef] [PubMed]

86. Thong, W.L.; Shin-Ya, K.; Nishiyama, M.; Kuzuyama, T. Methylbenzene-containing polyketides from a Streptomyces that spontaneously acquired rifampicin resistance: Structural elucidation and biosynthesis. J. Nat. Prod. 2016, 79, 857-864. [CrossRef] [PubMed]

87. Thong, W.L.; Shin-Ya, K.; Nishiyama, M.; Kuzuyama, T. Discovery of an antibacterial isoindolinone-containing tetracyclic polyketide by cryptic gene activation and characterization of its biosynthetic gene cluster. ACS Chem. Boil. 2018, 13, 2615-2622. [CrossRef]

88. Qi, H.; Ma, Z.; Xue, Z.; Ruan, H.; Yu, X.; Gao, M.; Wang, J. Two new compounds from rifamycin resistant mutant strain Streptomyces sp. HS-NF-1046R. Acta. Pharm. Sin. B 2019, 54, 117-121.

89. Jiménez, C. Marine natural products in medicinal chemistry. ACS Med. Chem. Lett. 2018, 9, 959-961. [CrossRef] 
90. Blunt, J.W.; Carroll, A.R.; Copp, B.R.; Davis, R.A.; Keyzers, R.A.; Prinsep, M.R. Marine natural products. Nat. Prod. Rep. 2018, 35, 8-53. [CrossRef]

91. Cashel, M.; Gallant, J. Two compounds implicated in the function of the RC gene of Escherichia coli. Nature 1969, 221, 838-841. [CrossRef]

92. Lai, C.; Xu, J.; Tozawa, Y.; Okamoto-Hosoya, Y.; Yao, X.; Ochi, K. Genetic and physiological characterization of rpoB mutations that activate antibiotic production in Streptomyces lividans. Microbiology 2002, 148, 3365-3373. [CrossRef] [PubMed]

93. Vigliotta, G.; Tredici, S.M.; Damiano, F.; Montinaro, M.R.; Pulimeno, R.; Di Summa, R.; Massardo, D.R.; Gnoni, G.V.; Alifano, P. Natural merodiploidy involving duplicated $r p o B$ alleles affects secondary metabolism in a producer actinomycete. Mol. Microbiol. 2005, 55, 396-412. [CrossRef] [PubMed]

94. Tala, A.; Wang, G.; Zemanova, M.; Okamoto, S.; Ochi, K.; Alifano, P. Activation of dormant bacterial genes by Nonomuraea sp. strain ATCC 39727 mutant-type RNA polymerase. J. Bacteriol. 2009, 191, 805-814. [CrossRef] [PubMed]

95. Artsimovitch, I.; Patlan, V.; Sekine, S.; Vassylyeva, M.; Hosaka, T.; Ochi, K.; Yokoyama, S.; Vassylyev, D.; Initiative, R.S.G. Structural basis for transcription regulation by alarmone ppGpp. Cell 2004, 117, 299-310. [CrossRef]

96. Okamoto-Hosoya, Y.; Hosaka, T.; Ochi, K. An aberrant protein synthesis activity is linked with antibiotic overproduction in rpsL mutants of Streptomyces coelicolor A3(2). Microbiology 2003, 149, 3299-3309. [CrossRef] [PubMed]

97. Hosaka, T.; Xu, J.; Ochi, K. Increased expression of ribosome recycling factor is responsible for the enhanced protein synthesis during the late growth phase in an antibiotic-overproducing Streptomyces coelicolor ribosomal rpsL mutant. Mol. Microbiol. 2006, 61, 883-897. [CrossRef] [PubMed]

98. Imai, Y.; Sato, S.; Tanaka, Y.; Ochi, K.; Hosaka, T. Lincomycin at subinhibitory concentrations potentiates secondary metabolite production by Streptomyces spp. Appl. Environ. Microbiol. 2015, 81, 3869-3879. [CrossRef] [PubMed]

99. Davies, J.; Spiegelman, G.B.; Yim, G. The world of subinhibitory antibiotic concentrations. Curr. Opin. Microbiol. 2006, 9, 445-453. [CrossRef] [PubMed]

(C) 2019 by the authors. Licensee MDPI, Basel, Switzerland. This article is an open access article distributed under the terms and conditions of the Creative Commons Attribution (CC BY) license (http://creativecommons.org/licenses/by/4.0/). 